\title{
Mao's Parades: State Spectacles in China in the 1950s*
}

Chang-tai Hung

\begin{abstract}
Political parades in the People's Republic of China are a rich and complex cultural text from which historians can gain a deeper understanding of the nature and policies of the Chinese Communist Party (CCP). The CCP's state spectacles, primarily the parades during the May Day and National Day (1 October) celebrations held in Tiananmen Square in the 1950s, were a well-organized political ritual with multiple purposes: festivals of iconoclasm, demolishing the old order and embracing the new era of socialism; a legitimation of the CCP's authority; a display of myriad achievements under communism; an affirmation of the centrality of Mao's role in modern Chinese revolutionary history; and an announcement of China's presence in the international socialist camp. The parades, although influenced by the Soviet Union, exhibited strong native colours. They also reflected a nation undergoing political and economic changes. In the end, Mao Zedong and his senior Party leaders, acting both as actors and directors, carefully controlled and choreographed the paraders, who were themselves the audience, in Tiananmen Square to heap praise on the achievements of the Party and its chairman.
\end{abstract}

On the morning of 3 February 1949, four days after the seizure of the Kuomintang (国民党)-controlled Beiping (北平, renamed Beijing in October 1949, its original name before 1928), the People's Liberation Army (PLA) marched into the fabled city with great fanfare, signalling an official changeover of power and the beginning of a new era in modern Chinese history. Commanders Lin Biao (林彪, 1907-71) and Luo Ronghuan (罗荣桓, 190263), positioned atop Zhengyang Gate (Zhengyangmen 正阳门), inspected the troops as they passed through the gate; the troops then immediately turned eastward into the heart of the legation quarter (Dongjiaominxiang 东交民巷), and then moved on to other parts of the city. A young American Fulbright scholar, Derk Bodde, witnessed this spectacular display of military might, and noted in his diary:

I missed the first contingents of infantry and cavalry, as well as part of the motorized units. But in what I did see, lasting about an hour, I counted over 250 heavy motor vehicles of all kinds - tanks, armored cars, truck loads of soldiers, trucks mounted with

\footnotetext{
* Research for this article was generously funded by a grant from the Research Grants Council, Hong Kong.

(C) The China Quarterly, 2007 doi:10.1017/S0305741007001269
} 
machine guns, trucks towing heavy artillery. Behind them followed innumerable ambulances, jeeps, and other smaller vehicles. As probably the greatest demonstration of Chinese military might in history, the spectacle was enormously impressive. But what made it especially memorable to Americans was the fact that it was primarily a display of American military equipment, virtually all of it captured or obtained by bribe from Kuomintang forces in the short space of two and one half years. ${ }^{1}$

But unknown to Bodde and many Beiping residents on that memorable day, this military parade was not casually put together. The event was carefully orchestrated and meticulously planned from the start by the Chinese Communist Party (CCP). On the evening of 29 January, Beiping's underground communist radio stations received a secret telegram from Liu Ren (刘仁, 190973), a high official and an organizer of the parade, with the instruction, "Line up the people in the streets to welcome [our troops]!"2 Planners calculated the route to generate the most dramatic and symbolic effect. By entering Beiping through Zhengyang Gate - the main southern entrance into the inner city, formerly reserved for emperors - and then marching into the legation quarter where foreigners had been prominent in bygone days, the Red Army was forcefully stating that it intended to demolish two evils of China's past: feudalism and imperialism. The communist army, envisaging a bright new world ahead, would now "liberate" China.

The rich cultural and political context of parades affords historians a deeper understanding of the nature of societies. This is clearly illustrated by the community celebrations (shehuo 社火) in traditional China, popular village parades held at the beginning of the lunar year when peasants paid tribute to local deities in the hope of reaping a bumper harvest. ${ }^{3}$ The CCP's military procession was rather different, however, with broad geographical antecedents and major political implications. Historically parades and processions have been central to politics. In his study of three different societies - Elizabethan England, 14th-century Java and 19th-century Morocco - Clifford Geertz has argued that the rulers used royal processions to "justify their existence and order their actions in terms of a collection of stories, ceremonies, insignia, formalities, and appurtenances that they have either inherited or, in more revolutionary situations, invented."4 During the French Revolution, as Mona Ozouf contended, festivals and parades marked by popular participation and held in open fields were vital parts of a new revolutionary culture that emphasized the openness and equality of a modern, secular world. ${ }^{5}$ Nazi culture thrived on mass rallies. Hitler was a master at emotionally manipulating crowds through

1 Derk Bodde, Peking Diary: A Year of Revolution (New York: Henry Schuman, 1950), pp. $103-04$.

2 Mianhuai Liu Ren tongzhi (Remembering Comrade Liu Ren) (Beijing: Beijing chubanshe, 1979), p. 111.

3 Dong Xiaoping, Tianye minsuzhi (Folklore Fieldwork) (Beijing: Beijing shifan daxue chubanshe, 2003), pp. 612-26.

4 Clifford Geertz, "Centers, kings, and charisma: reflections on the symbolics of power," in Geertz, Local Knowledge: Further Essays in Interpretive Anthropology (New York: Basic Books, 1983), p. 124.

5 Mona Ozouf, Festivals and the French Revolution, trans. Alan Sheridan (Cambridge, MA: Harvard University Press, 1988), pp. 126-57. 
co-ordinated marches and mammoth sports events. ${ }^{6}$ In the Soviet Union, celebrations in Red Square during May Day and on the anniversary of the October Revolution were affirmations of Soviet authority and the supremacy of a socialist system. ${ }^{7}$ In the United States, parades such as those celebrating America's independence on 4 July are civic dramas and communal festivals, which, in the words of Mary Ryan, represent "an exercise in popular sovereignty." "How do the Chinese communist parades compare to these?

Studies of Chinese state spectacles have significantly advanced our understanding of the roles of ritual and symbolism in the development of nationalism. Recent works on the National Day (10 October) celebrations to honour the anniversary of the 1911 Revolution have shed light on the development of a new national community in early Republican China. ${ }^{9}$ One art historian's study of state parades on 1 October in socialist China offers some insights into communist political ritual and symbolism. ${ }^{10}$ But few have examined how these state spectacles were organized institutionally or identified the key planners; even fewer have looked into the influence of Western state ceremonies on Chinese parades (in the case of socialist China, it was the Soviet model). This article attempts to fill these gaps by examining both the official agencies responsible for staging state parades in China in the 1950s and the Soviet influence on the staging process. More importantly, it seeks to understand the nature of Chinese state spectacles, focusing not only on the National Day (1 October) parades but also on the May Day celebrations held in Tiananmen Square (天安门广场) in the 1950s. I argue that the parades of the CCP were wellorganized political rituals with multiple purposes: they were festivals to highlight the demolition of the old order and to embrace the new socialism; a legitimation of the CCP's authority; a display of myriad achievements under communism; an affirmation of the centrality of the role of Mao Zedong (1893-1976) in modern Chinese revolutionary history (hence expressing the cult of Mao); and an announcement of China's presence in the international socialist camp. The parades also reflected a nation undergoing political and economic changes at the time. Although celebrations and parades were also staged in major cities such as Shanghai, the ones in the capital were the most memorable and significant, and

6 George Mosse, The Nationalization of the Masses: Political Symbolism and Mass Movements in Germany from the Napoleonic Wars through the Third Reich (Ithaca: Cornell University Press, 1975), pp. 100-26.

7 Christel Lane, The Rites of Rulers: Ritual in Industrial Society - The Soviet Case (Cambridge: Cambridge University Press, 1981), pp. 153-88.

8 Mary Ryan, "The American parade: representations of the nineteenth-century social order," in Lynn Hunt (ed.), The New Cultural History (Berkeley: University of California Press, 1989), p. 138.

9 Henrietta Harrison, The Making of the Republican Citizen: Political Ceremonies and Symbols in China, 1911-1929 (Oxford: Oxford University Press, 2000), pp. 93-132.

10 Wu Hung, Remaking Beijing: Tiananmen Square and the Creation of a Political Space (Chicago: University of Chicago Press, 2005), pp. 85-104. 
provided a model for others to follow. Local observers were often sent to the capital to learn from the Beijing experience. ${ }^{11}$

\section{City Decorations and Mass Celebrations}

Because of political and social uncertainties, the National Day celebrations in the early Republican era were held intermittently by the warlord government in Beijing, and later by the Kuomintang in Nanjing. In the first two decades of the 20th century military processions on National Day were occasionally staged by warlords in Tiananmen Square and Nanyuan (南苑), a military base south of Beijing, but in the late 1920s the Kuomintang regime held them at Nanjing's airfield. ${ }^{12}$ Few large-scale parades, however, were organized by the state, and festivities often displayed an impromptu spirit. ${ }^{13}$ A typical celebration of National Day in this period was described by Shanghai's influential newspaper Shenbao (申报 Shanghai News) as the public's enthusiastic decoration of the cities with national flags and lanterns. ${ }^{14}$

In December 1949, soon after the founding of the People's Republic of China (PRC), the government officially announced a list of new public holidays and festivals to signal the destruction of the feudal past and the beginning of a novel era - a pronouncement resembling that of the French and October Revolutions. ${ }^{15}$ These festivals included May Day (1 May), the Youth Festival (4 May), the founding of the PLA (1 August) and National Day (1 October). The most memorable and politically significant of these festivals were May Day and National Day, to be marked by massive parades and great revelry.

Like the Soviet festivals, ${ }^{16}$ the CCP's state celebrations consisted of three basic components: ceremonial decoration of the city, mass spectacles and, most important, processions conveying visually stunning scenes and compelling political messages. Decoration of the city of Beijing began weeks before May Day and National Day. Red banners and posters were displayed on buildings and at roadsides; shop windows and street signs were decorated with slogans and red stars. Displays varied in different parts of the city. Areas around Tiananmen Square, the symbolic centre, received the lion's share, as evidenced in the streets fronting Zhengyang Gate, known also as Qianmen (前门), or Front Gate. Similarly, the People's Square in central Shanghai drew the most attention. For the 1951 National Day celebrations, Shanghai's Municipal Communist Party ordered that the main roads leading to the People's Square, especially Nanjing Road (南京路) and Tibet Road (西藏路), the two key parade routes, should be

11 Wang Fengde, "Baogao" ("Report"), Shanghai Municipal Archives (SMA), A22-2-894.

12 Shenbao, 14 October 1914; 11 October 1916; 10 October 1917; 10 October, 1929; 12 October 1929.

13 Schools sometimes organized impromptu celebrations. For example, on 10 October 1917 more than 4,757 students in Shanghai participated in a parade to celebrate National Day. See Shenbao, 11 October 1917.

14 Shenbao, 12 October 1917; 11 October 1919; 10 October 1929.

15 Renmin ribao (People's Daily), 24 December 1949.

16 Lane, The Rites of Rulers, p. 172. 
“the focus of honour." 17 Park Hotel (Guoji fandian 国际饭店), directly facing the square and one of the tallest buildings in Asia at the time, was to be draped with gigantic festoons of red cloth bearing slogans such as "Long live Chairman Mao Zedong, the great leader of the Chinese people!" 18

Mass spectacles consisted of a series of public celebrations closely directed by the government. In Beijing free garden parties were held in the Workers' Cultural Palace (formerly the Imperial Ancestral Temple) and Zhongshan Park (中山公园) to the east and west of Tiananmen, respectively, as well as in the Summer Palace and other locations, with thousands of citizens participating. Dancing revelries were held in Tiananmen Square at night, as were firework displays. ${ }^{19}$ Citizens set off firecrackers and watched patriotic movies in open-air theatres in Dongdan and Xidan. ${ }^{20}$ In these events, the people, according to Renmin huabao (人民画报 China Pictorial), were all “warmly applauding a new China.",21

\section{The Parades}

The greatest public and international attention was focused on the annual May Day and National Day processions in Tiananmen Square and, in Shanghai, in the People's Square (see Figure 1). The first procession was on 1 October 1949, immediately after Mao proclaimed, atop Tiananmen, the founding of the People's Republic. The procession began with a military parade, followed by thousands of cheerful civilians marching across Tiananmen Square. Mao attached great importance to this Founding Day military parade, remarking that "since this is the first such parade of our new nation, it must be a great success!" 22 The paraders, holding huge portraits of national leaders such as Mao, swaying rhythmically to the waist drums they played and dancing yangge (秧歌), the traditional rural dance of north China, passed through the Left Chang'an Gate (长安左门, known at the time as East Sanzuomen (东三座门)) into the still enclosed Tiananmen Square, filed passed Tiananmen to be reviewed by the nation's new rulers, exited through the Right Chang'an Gate (长安右门, known as West Sanzuomen (西三座门)), and finally dispersed to nearby streets. The grand procession would be repeated twice a year.

In 1951, the municipal government set up two committees: the Capital's preparatory committee for the celebration of the founding of the People's

17 "Yijiuwuwu nian 'Wuyi' jie shirong buzhi gongzuo jihua" ("Work plans for decorating the city during the 1955 May Day festival"), SMA, B56-2-3.

18 "Guanyu jige zhuyao de gaolou daxia de jufu biaoyu de buzhi" ("On the decoration of huge posters on the key high-rises"), SMA, B56-2-2.

19 "Guanyu Wuyi youxing he wanhui zhunbei qingkuang de baogao" ("Report on the preparation for the May Day parades and evening parties"), Beijing Municipal Archives (BMA), 99-1-110.

20 Zhongguo renmin zhengzhi xieshang huiyi Beijingshi weiyuanhui wenshi ziliao weiyuanhui (ed.), Zhuangyan de qingdian (Solemn Festivities) (Beijing: Beijing chubanshe, 1996), p. 151.

21 Renmin huabao (China Pictorials), Vol. 1, No. 1 (1950), photos.

22 Shu Jun, Tiananmen guangchang lishi dang'an (The Historical Documents of Tiananmen Square) (Beijing: Zhonggong zhongyang dangxiao chubanshe, 1998), p. 227. 
Figure 1: The Art Group in the National Day Parade, 1 October 1954, Tiananmen Square, Beijing

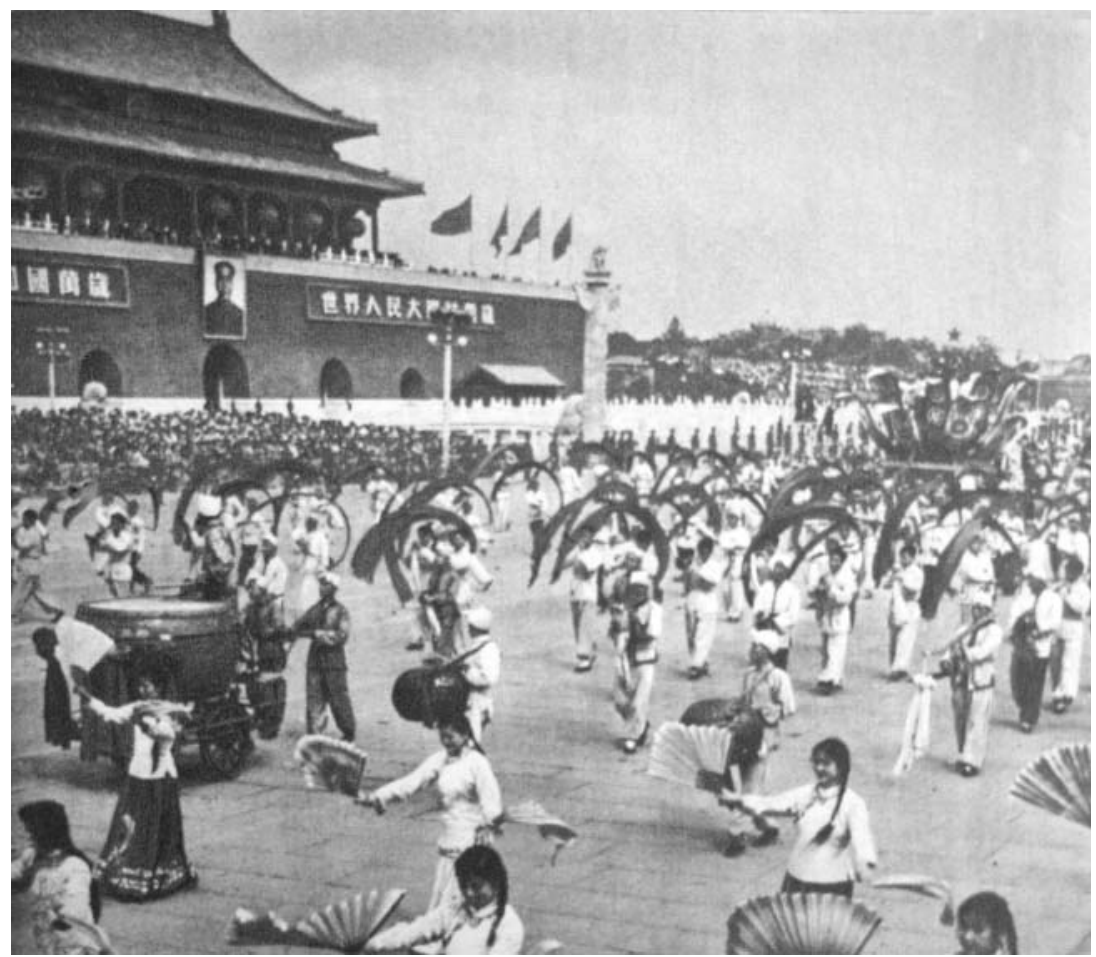

Source:

Renmin huabao (China Pictorial), No. 10 (1954), p. 3.

Republic of China (Shoudu qingzhu Zhonghua renmin gongheguo guoqingjie choubei weiyuanhui 首都庆祝中华人民共和国国庆节筹备委员会) and the Beijing preparatory committee for the celebration of international labour day (Beijing qingzhu Wuyi guoji laodongjie choubei weiyuanhui 北京庆祝五一国际 劳动节筹备委员会). Each committee resembled the Soviet Union's central staff for the conducting of holidays ${ }^{23}$ and was responsible for co-ordinating activities during the parade. But whereas the Soviet committee was not created until 193031, almost 15 years after the Bolshevik revolution, the two Beijing committees were established in the early days of the PRC, attesting to the Communists' urgency for control. They were nominally under Beijing's municipal government, with the mayor, Peng Zhen (彭真, 1902-97), overseeing their organization of the parades. ${ }^{24}$ Their directives, however, came from the top.

24 "Qunzhong youxing duiwu zuzhi fang'an deng" ("The plan for organizing contingents of the procession for the people's parade and others"), BMA, 99-1-1. 
Every year, in the early mornings of 1 May and 1 October, the paraders assembled at designated places at Tiananmen Square, usually at the eastern, southern and northern sides such as Wufujing (王府井) and Dongdan (东单). ${ }^{25}$ Some gathered as early as 3 o'clock in preparation for the procession that would start at 10 o'clock. ${ }^{26}$ The parades had been well rehearsed, usually at night, beginning at least three months earlier. As at the first procession in October 1949, they had two components, one military and the other civilian, the latter commonly known as “the people's parade" (qunzhong youxing 群众游行). The military component headed the ceremony, with detachments of various PLA divisions marching in different formations, accompanied by a weaponry show. Then came the civilian part, involving hundreds of thousands of workers, peasants, students and artists. ${ }^{27}$ After 1952, however, May Day parades eliminated the military portion, retaining only the civilian part. ${ }^{28}$ The performance of this political ritual was never simple. Contrary to the optimistic official reports, the organizers encountered many problems.

In the first two years of the PRC, the Young Pioneers, representing the future of the nation, led the procession immediately following the military parade. The Young Pioneers were mostly primary school students drawn from schools near Tiananmen Square so as to reduce the inconvenience of long-distance travel for the youngsters during rehearsals and the actual performance. ${ }^{29}$ For many participants, this assignment carried much honour. "When I found out that I was the only one selected from my primary school to take part in the National Day parade, I felt truly blessed [wo gandao feichang xingfu 我感到非常幸福], recalled one female former Young Pioneer, who came from a devoted communist family. "My grandmother even made me a bright red dress for this exhilarating occasion. But during the ceremony," she added, "I had to wear a white uniform over the dress." 30 The Young Pioneers were followed by workers, peasants, government employees, students, and literary and art groups. ${ }^{31}$ In subsequent years other contingents were added, including honour guards, athletes, urban residents from different districts (chengqu 城区), and representatives from industrial and commercial sectors, who were included because they had, according to official records, "vowed to smash capitalism and help establish socialism." 32 By 1951 a more-or-less standard pattern was established, with ten groups representing different constituents in the following

25 "Youxing duiwu xulie he xingjin luxian" ("The order of processions and the procession routes"), BMA, 99-1-61.

26 "Biandui gongzuo de jixiang guiding" ("Rules concerning group formations"), BMA, 99-1-200.

27 "The plan for organizing contingents of the procession."

28 Renmin ribao, 3 May 1952.

29 Interview with Marcher A, 6 January 2006, Beijing; interview with Marcher B, 13 January 2006, Beijing.

30 Interview with Marcher C, 4, 5 January 2006, Beijing.

31 "Yijiuwuyi nian guoqingjie youxing jihua" ("Plan of the parade at the 1951 National Day celebration"), BMA, 99-1-1.

32 "Youxing duiwu jieshao" ("Introduction to groups that participated in the parades"), BMA, 99-1162. 
order: honour guards, Young Pioneers, workers, peasants, government employees, urbanites, representatives from industrial and commercial sectors, students, artists and performers, and athletes. ${ }^{33}$ The art group performed colourful dances, and at the end of the parade there were mass gymnastic displays to illustrate controlled and well-coordinated body movements, a sign of discipline and order. Other cities followed this pattern, though slight regional variations did occur, as in the case of Shanghai, where a lively torch relay was added to the National Day parade in $1959 .{ }^{34}$

The marchers generally formed nine columns, with 110 people lined up side by side. That number increased to 150 in 1959, when Tiananmen Square and East and West Chang'an avenues (dongxi Chang'an jie 东西长安街) were greatly enlarged in time for the celebration of the tenth anniversary of the founding of the PRC. ${ }^{35}$ The total number of people participating in the processions ranged from 300,000 to $450,000 .^{36}$ An additional 50,000 to 100,000 people, all holding banners, also assembled in the square, forming an impressive political symbol. ${ }^{37}$ "It was a massive gathering of people, filled with pride and joy," reported one marcher who participated in the 1956, 1957 and 1958 National Day spectacles in Tiananmen Square. ${ }^{38}$ The entire parade, including both the military and civilian components, usually lasted less than three hours, with the civilian part occupying three-quarters of the time. ${ }^{39}$

Common to all the parades were multicoloured floats, red banners, decorated models, huge balloons, loud music, lively dancing, bright costumes and finally, as a symbol of peace, the releasing of doves. Replicas of industrial machinery and agricultural tools helped to enhance the procession..$^{40}$ In the lead the honour guards carried huge national flags, displaying the national emblem and portraits of communist leaders, with Mao's photo predominating. Portraits of Mao and Sun Yat-sen (孙逸仙, 1866-1925) led the way in the 1951 National Day celebration. ${ }^{41}$ Then followed, in the second row, photos of Zhou Enlai (周恩来, 1898-1976), Liu Shaoqi (刘少奇, 1898-1969) and Zhu De (朱德, 1886-1976); the faces of Marx, Engels, Lenin and Stalin appeared in the third row, followed by pictures of foreign socialist leaders, commonly known as "people's leaders" (renmin lingxiu 人民领袖), such as Kim Il-sung, Ho Chi Minh, Lazar M. Kaganovich and Nikita Khrushchev. ${ }^{42}$

33 "Gongzuo richeng he jianbao" ("Work schedule and brief reports "), BMA, 99-1-13.

34 On Shanghai's torch relay race, see SMA, B55-2-6.

35 "Rules concerning group formations."

36 "Youxing renshu" ("The number of people who participated in the parades"), BMA, 99-1-94.

37 Ibid.; Solemn Festivities, p. 83.

38 Interview with Marcher D, 5 January 2006, Beijing.

39 "Qunzhong youxin zhunbei gongzuo qingkuang de baogao" ("Report on the preparation of the people's parade"), BMA, 99-1-94.

40 "Ge duiwu duirong qingkuang" ("Specific conditions in each parade group"), BMA, 99-1-45.

41 "Lingxiuxiang pailie shunxu ji qizhi pailie de guiding" ("Rules concerning the order of the leaders and the banners"), BMA, 99-1-1.

42 "Guanyu youxing duiwu zhong suo tai lingxiuxiang ji pailie shunxu de zhongyao tongzhi" ("The important announcement concerning the order of leaders' portraits during the procession"), SMA, B55-1-5. 
The sequence of these photos varied somewhat, but the dominance of Mao was clearly evident. Scholars have long suggested the importance of the Mao cult in the formation of Chinese political culture, ${ }^{43}$ and the state spectacles in the 1950s no doubt added another dimension to the growing deification of Mao since the founding of the PRC.

In the 1955 National Day celebration, for example, Sun's portrait was relegated to the second row, behind photos of Mao, Liu Shaoqi, Zhou Enlai, Zhu De and Chen Yun (陈云, 1905-95). In the 1950s Mao's portrait was sometimes mixed in with those of other senior CCP members, but still the chairman's pre-eminence was without question, for his image was always closest to Tiananmen, the place deemed most sacred in the entire procession. Even when, in the earlier parades, Mao's portrait appeared with Sun Yat-sen's, Mao's was displayed closer to Tiananmen and hence seen as more important. ${ }^{44}$ The only time when Mao's portrait was not in the front was during the annual May Day parade, in which the front row featured portraits of foreign communist leaders. ${ }^{45}$ However, the May Day celebration was to commemorate the triumph of the proletariat worldwide, not just in China, and universal symbols such as the hammer and sickle were visible everywhere. ${ }^{46}$

Political rhetoric occupied a special place in the Chinese parades, as it had in the French and Bolshevik revolutions. ${ }^{47}$ "In politics," writes Pierre Bourdieu, "'to say is to do,' that is, it is to get people to believe that you can do what you say and, in particular, to get them to know and recognize the principles of division of the social world, the slogans, which produce their own verification by producing groups and, thereby, a social order." ${ }^{48}$ Two kinds of political rhetoric were generally evident in the parades: placards (biaoyu 标语) carried by marchers bearing political sayings and slogans (kouhao 口号) or catchphrases shouted in unison during the processions. "Long live the People's Republic of China!" and "We must liberate Taiwan!" were recurrent slogans. ${ }^{49}$ The Mao cult gained fresh impetus because of the numerous slogans uttered in his name. "We had to repeat the slogan 'Long live Chairman Mao!' many times," said one

43 Stuart R. Schram, "Party leader or true ruler? Foundations and significance of Mao Zedong's personal power," in Schram (ed.), Foundations and Limits of State Power in China (London: School of Oriental and African Studies/Hong Kong: Chinese University Press, 1987), pp. 203-56; Geremie R. Barmé, Shades of Mao: The Posthumous Cult of the Great Leader (Armonk, NY: M.E. Sharpe, 1996), pp. $3-73$.

44 Putian tongqing (The Whole World Joins in the Celebration), a film produced by Beijing dianying zhipianchang (Beijing Film Studio), 1950; Yijiuwuyi nian guoqingjie: Daxing jilupian (The 1951 National Parade: A Major Documentary), a film produced by Zhongyang dianyingju Beijing dianying zhipianchang (Beijing Film Studio, the Central Film Bureau), 1951.

45 "'Wuyi' jie youxing duiwu lingxiuxiang pailie banfa" ("Methods to arrange the order of the leaders' portraits during the May Day parade"), BMA, 99-1-3.

46 "Shaoxiandui" ("The Young Pioneers group"), BMA, 99-1-196.

47 Lynn Hunt, Politics, Culture, and Class in the French Revolution (Berkeley: University of California Press, 1984), pp. 19-51; Lane, The Rites of Rituals, p. 167.

48 Pierre Bourdieu, Language and Symbolic Power, ed. and intro. John B. Thompson, trans. Gino Raymond and Matthew Adamson (Cambridge, MA: Harvard University Press, 1991), p. 190.

49 "Huhuan de kouhao" ("Slogans used"), BMA, 99-1-94. 
Young Pioneer woman, fondly recalling her memorable moments in Tiananmen Square. ${ }^{50}$ Although this glorification of Mao was carefully engineered by the CCP, the marchers I interviewed all expressed their reverence for the chairman, indicating the supreme authority Mao enjoyed in the Party at the time. ${ }^{51}$ Other slogans were related to individual events. In the 1951 National Day parade, for instance, the unfolding conflicts in Korea were evident in the military nature of the slogans, such as "Salute the People's Liberation Army!" "Salute the People's Voluntary Army!" "Celebrate the victory of the people of China and Korea!" 52 Watchwords in the May Day parades communicated similar themes but with an emphasis on internationalism. Those in the 1957 May Day procession declared, for example, "Long live the great unity of the proletariat worldwide!" "Long live Marxism-Leninism!" "Long live the socialist camp led by the Soviet Union!" 53

Another major theme of the processions was the unity of different nationalities, underscoring China as a harmonious nation where people lived peacefully together. The issue of nationalities was a sensitive matter given the tense situation in Tibet, for example, in late 1950, where Chinese communist troops completed the CCP's unification campaign. Not surprisingly, the "Unity of nationalities" theme was choreographed as a popular dance and also appeared in slogans. ${ }^{54}$

Paraders were told to show "passionate spirit" when entering Tiananmen Square and to wave to the spectators on the reviewing stands as they approached from the east. ${ }^{55}$ The high point came when the columns filed past Tiananmen to be reviewed by the nation's leaders. This element of the parade closely resembled the design of Soviet parades, where paraders marched past Lenin's mausoleum and were greeted by leaders from an elevated platform on top of the mausoleum. ${ }^{56} \mathrm{~A}$ new tradition was added by the Chinese, however. Immediately after all the columns had passed Tiananmen, the assembled crowd, made up largely of workers and Young Pioneers who were responsible for forming various artistic patterns during the parades, rushed to Gold Water Bridge (Jinshuiqiao 金水桥) in front of Tiananmen to cheer and greet the national leaders. This was accompanied by uplifting tunes such as "Unity is the strength" to signal the close bonding among Chinese who shared similar goals. ${ }^{57}$

Especially memorable was the parade in 1959 celebrating the tenth anniversary of the founding of the PRC. A spectacular procession was staged in the capital and in major cities such as Shanghai. ${ }^{58}$ More than 40 foreign

50 Interview with Marcher C.

51 Interviews with Marchers A, B, C and D; and interview with Marcher E, 7 January 2006, Beijing.

52 "Beijingshi qingzhu guoqing dahui kouhao" ("Slogans used by Beijing to celebrate the National Day celebrations"), BMA, 99-1-11.

53 "Report on the preparation for the May Day parades and evening parties."

54 "Ge duiwu duirong qingkuang" ("Specific conditions in each parade group"), BMA, 99-1-61.

55 "Youxing jihua" ("The plans for the parade"), BMA, 99-1-2.

56 Lane, The Rites of Rituals, p. 156.

57 "Di san ci zhihuibu huiyi" ("The third meeting of the command centre"), BMA, 99-1-47. This is also known as "Advancing forward in unison" (Yiyong er shang). See also Solemn Festivities, p. 50.

58 On Shanghai's celebrations of this special occasion, see SMA, B55-1-14. 
government dignitaries, including Khrushchev, were invited to Beijing to attend the ceremony, ${ }^{59}$ and a new segment of local militia joined the marching columns. ${ }^{60}$ The number of participants in the columns was also increased from 110 to 150 , forming one of the largest parades in the history of contemporary China. ${ }^{61}$

\section{Themes}

Political and economic themes dominated the two parades each year, but the processions emphasized different specific themes according to the year's various political campaigns. Earlier parades focused on the "Resist America and aid Korea" campaign and on denouncing foreign imperialists, especially Americans. ${ }^{62}$ The First Five-Year Plan (1953-57) dominated the parade in the mid-1950s. ${ }^{63}$ In the later 1950s the focus was the Great Leap Forward and the People's Commune, epitomized by the campaign slogans "More, quicker, better, cheaper" and "Long live the People's Commune." 64

The honour guards and Young Pioneers were the first ceremonial groups to open the show representing, respectively, the start of the celebration and the successors to the communist revolution. That the workers marched directly behind these two groups was evidence of their commanding presence in the socialist regime, as enshrined in the Organic Law promulgated by the Chinese government in 1949 which declared that workers were the leading force in the new republic. This view, of course, was squarely in line with the MarxistLeninism orthodoxy underlying the Chinese communist revolution.

Immediately following the workers were the peasants, symbolic of the bond between the two classes and a familiar theme in socialist rhetoric that was reinforced by the hammer-and-sickle icon displayed everywhere. Close bond notwithstanding, the hegemonic status of the proletariat was unmistakable, as even the honour guards were mostly workers. ${ }^{65}$ Indeed, workers were by far the largest group in the marching columns, numbering several times more than peasants. In the 1952 National Day parade, for example, 85,000 workers participated compared to only 20,000 peasants. $^{66}$ Moreover, the parade organizers gave workers the most important placards and signs to carry. In the 1953 National Day celebration, workers held the key banner, "Celebrating

59 Solemn Festivities, p. 487.

60 Ibid. p. 90.

61 "Shoudu qingzhu shi zhounian guoqingjie youxing zuzhi gongzuo yaodian (caoan)" ("Key points concerning the parade during the tenth anniversary of the National Day celebration: a draft"), BMA, 99-1-193.

62 "Beijingshi qingzhu guoqing dahui kouhao" ("Beijing's slogans used in the National Day celebrations"), BMA, 99-1-1.

63 "Yijiuwuwu nian guoqingie qunzhong youxing shi huhuan de kouhao" ("Slogans used during the 1955 National Day's people parade"), BMA, 99-1-61.

64 "Duirong" ("Groups"), BMA, 99-1-144.

65 Solemn Festivities, pp. 89, 271.

66 "Jihua renshu" ("The projected figures"), BMA, 99-1-2. 
the successful opening of the Eighth Party Congress!"67 Thus the workers' symbolic, leading role in the new socialist state was explicit. Also evident in the parades was the workers' pride. "I felt particularly honoured when Chairman Mao reviewed the workers," one worker marcher who had participated many times in both the biannual parades from 1949 to the early 1960s reported. ${ }^{68}$

The parades were not meant to be nationalistic. In fact, the Chinese Communists had proclaimed that the revolution was part of the international socialist movement, and parade organizers actively promoted a global spirit, as shown by the inclusion of the ubiquitous icon of hammer and sickle and portraits of Marx, Engels, Lenin and Stalin. The friendship between China and the Soviet Union, and the leading role of the Soviet Union in world communism, were underscored in placards and slogans, a sign of China's gratitude to Moscow for its economic and technological aid during the 1950s.

The spirit of internationalism was especially accentuated during May Day, the international labour day that was a foreign-inspired festival and a worldwide event to commemorate the workers' struggle against capitalism and oppression. During a preparatory session for the 1956 May Day parade, when discussing whether Mao's portrait would be the only one displayed, Peng Zhen responded: "Holding only the portrait of Chairman Mao will make foreigners uncertain about our real stance on internationalism." ${ }^{\prime 69}$ Even so, national themes often overwhelmed the international spirit of the celebrations. Although foreign music was played, "it should be used only when appropriate," one official document stated, "with the main focus remaining the Chinese pieces." probably came directly from Mao, for he had ordered that the celebrations must "centre on China" (yi wo weizhu 以我为主). ${ }^{71}$

The emphasis on indigenous products was particularly apparent in the use of many native art forms. Revolutions, of course, entail the creation of new symbols antithetical to those of the past, but the communist revolutionaries often drew models and visual signs with popular resonance. As noted, the lively yangge dance and the playing of waist drums were two of the most dazzling folk performances in line with Mao's instructions. The Chinese lotus dance was another perennial favourite, ${ }^{72}$ and equally appealing were the dragon dance, especially the Sichuan (四川) version, and the lion dance. ${ }^{73}$ Native colour was included through a rich variety of local performance art, such as Shandong's (山 东) umbrella dance which was adopted in the 1956 National Day festivities. ${ }^{74}$

67 "Beijing qingzhu yijiuwuliu nian guoqingjie qunzhong youxing duiwu duirong qingkuang" ("On various parade groups during the 1956 National Day festival in Beijing”), BMA, 99-1-94.

68 Interview with Marcher E.

69 "Peng Zhen tongzhi zhaoji de "Wuyi' choubei gongzuo huiyi jilu" ("The minutes of the preparatory work concerning the May Day parade called by Comrade Peng Zhen”), BMA, 99-1-93.

70 "Gongzuo richeng" ("Work schedule") (1953), BMA, 99-1-32.

71 Solemn Festivities, p. 47.

72 Interview with Marcher A.

73 "Report on the preparation for the May Day parades and evening parties."

74 "Wenyi dadui muqian gongzuo jinxing qingkuang" ("The progress of the work of the art group"), BMA, 99-1-95. 
The emphasis on Chinese forms was partly for practical reasons, for they readily appealed to Chinese audiences, but even more important was their ability to demonstrate the value of a national art, a spirit of the new nation's independence. In fact, the more internationally oriented May Day parade paled in comparison with the National Day parade in both scale and symbolic significance. Party leaders often saw the May Day marches as mere preparation for the more significant event to come, the National Day celebration in October. This proved to be the case on the tenth anniversary of the National Day parade in 1959. That year's May Day celebrations were pronounced as a "grand rehearsal" for the forthcoming National Day festivities. ${ }^{75}$

\section{Organization and Control}

One of the most distinctive features of the state spectacles was, without question, the CCP's tight organization and careful monitoring system. As a Leninist organization, the Party naturally demanded that all decisions be carried out unquestioningly and efficiently. Uncertainties and instabilities during the early years of the PRC also required the government to be extremely cautious in critical security matters. Despite the festive spirit, the state parades were planned under close supervision, partly because of safety reasons. On 4 May 1949, for example, Kuomintang air attacks against the southern Beijing airport caused great alarm. ${ }^{76}$ On 6 February 1950 Shanghai was hit, and Kuomintang bombers destroyed the city's power plants and disrupted its water supply systems. ${ }^{77}$ In 1950 Chinese security police uncovered a plot allegedly engineered by American spies who planned to kill Mao and other senior officials by firing a mortar shell at Tiananmen during the National Day parade. Several involved were imprisoned, and two of them, an Italian, Antonio Riva, and a Japanese, Yamaguchi Ryuichi, were executed a year later. ${ }^{78}$

Careful organization was needed not only for safety reasons. The immense scale demanded that everything must be co-ordinated meticulously, for they were state functions that were expected to run smoothly with no mistakes. I contend, however, that tight control was prompted more by the CCP's anxiety about its very existence, especially in the early years of the PRC. The parades were always carefully and forcefully directed by central leaders, with little room for grassroots initiatives or spontaneous action. The spectacles were mounted through a series of controls, some by visible institutional means, others by personal influence and higher-level directions. Hence there was a central

75 "Zuzhi gongzuo yaodian” (“Important organizational matters”), BMA, 99-1-178.

76 Solemn Festivities, p. 56.

77 "Guanyu yijiujiuwuling nian er yue liu ri Yangshupu fadianchang zaoshou Guomindang feiji hongzha de baogao" ("Report on the bombing of Yangshupu's power plant by Kuomintang planes on 6 February 1950"), SMA, B1-2-390-1.

78 The key American spy was said to be David Barrett, a former military attaché of the US Embassy in China. For the alleged plot to kill Mao, see Renmin ribao, 18 August 1951. 
committee responsible for overall management, supervision by Party and government officials, and influence by senior Party members.

Organizationally, the annual parades were planned in Beijing by the two committees mentioned above. Other departments, municipal and central, also participated in overseeing the planning. In 1950, as the archival sources reveal, the Cultural Bureau (Wenhuaju 文化局) of the Municipal Party and the State Department's Ministry of Culture also took part in the planning processes. ${ }^{79}$ Most important, the Propaganda Department of the CCP Central Committee, which was headed by $\mathrm{Lu}$ Dingyi (陆定一, 1906-96) and was the most authoritative Party machinery in charge of ideological matters, monitored all decisions regarding the parades, including giving final approval of the slogans. ${ }^{80}$ "No single unit is allowed to come up with its own slogans," a 1955 central Party directive clearly stipulated. ${ }^{81}$

High-level institutional control was only part of the story. Senior Party leaders never failed to keep a close eye on the entire planning of the state celebrations. The active involvement of Politburo member and mayor Peng Zhen in the preparation of the parades was well known. In one of the preparatory sessions for the 1955 May Day parades, for instance, when a dispute arose concerning whether to use the portrait of Sun Yat-sen, the mayor gave his affirmation, saying: "To leave out Sun Yat-sen's portrait would be a mistake, for he contributed to the democratic revolution." $" 82$

Peng was not the only senior Party member to be involved. Others included vice-premier Chen Yi (陈毅, 1901-72), vice-minister of culture Qian Junrui (钱俊 瑞, 1908-85) and municipal Party vice-secretary Liu Ren. ${ }^{83}$ Premier Zhou Enlai, although not known for his direct role, took a personal interest in the events, especially cultural affairs. It was said, in 1955, that the premier "personally reviewed the art programmes." 84 This was no surprise, as Zhou's interest in literary and artistic activities was well known, as were his close ties with many influential artists and intellectuals sympathetic to the communist cause. Documents also reveal that in later years, especially during the Cultural Revolution, the premier's endorsement was needed for the parade events to take place. ${ }^{85}$ To many Party loyalists, firm discipline and tight control were signs that the CCP was in charge. After observing the parade in the capital, a Shanghai municipal delegate reported, with admiration, that "the Beijing Municipal Party surely had a tight grip on the contents of the parade." 86

79 "Qingzhu yijiuwuwu nian shoudu guoqingjie wenyi dadui gongzuo zongjie" ("Final report on the work of the art group during the 1955 National Day celebrations in the capital"), BMA, 99-1-62.

80 "Gongzuo jianbao" ("Brief reports"), BMA, 99-1-46.

81 "Di er ci zhihuibu huiyi" ("The second meeting of the command centre"), BMA, 99-1-47.

82 "The third meeting of the command centre".

83 "Final report on the work of the art group."

84 Ibid.

85 "Zhou zongli dui Shigeweihui guanyu yijiuqier nian 'Wuyi' jie qingzhu huodong de qingshi de pishi" ("Premier Zhou's decision on the petition submitted by the Beijing Municipal Revolutionary Committee concerning the 1972 May Day celebratory activities"), BMA, 99-1-784.

86 Wang Fengde, "Report." 


\section{A Spatial Political Hierarchy}

The significance of the CCP's grand parades can be examined from yet another angle: the politics of space in the development of the cult of Mao Zedong as a supreme leader within a spatial hierarchy, a series of concentric circles where the outermost ring represents the capital Beijing, and the inner rings correspond to Tiananmen Square, Tiananmen, Mao's senior associates, finally centring on Chairman Mao as the new nation incarnate.

Beijing had undergone major reconstruction in the early 1950s, ${ }^{87}$ the centrepiece of which was Tiananmen Square, a project that included tearing down old city walls and removing decorated archways (pailou 牌楼). The symbolism in the expansion of Tiananmen Square was most significant. The square, which Mao viewed as the space where the history of the CCP began with the May Fourth student demonstrations against imperialism in $1919,{ }^{88}$ was to be converted from an enclosed, forbidden area to a people's square, where "the masses could celebrate together with great excitement," as the Party-controlled Renmin ribao (人民日报 People's Daily) described. ${ }^{89}$

A primary goal in expanding Tiananmen Square was undoubtedly to accommodate the two annual parades and the large crowd of spectators. It was heavily influenced by the Soviet experience, particularly the enlargement of Red Square in the 1930s, ${ }^{90}$ although the Tiananmen reconstruction was on an even grander scale. In the Soviet case, the Chinatown Wall and Iberian Chapel were removed, and Gorky Street (now Tverskaya Street), the main boulevard leading to Red Square, was rebuilt to accommodate huge public demonstrations on May Day and on the anniversary of the October Revolution. ${ }^{91}$ Red Square was greatly enlarged so that, in the words of Lazar Kaganovich, the demonstrators from different districts of Moscow could "pour into Red Square at the same time," generating a spirit of unprecedented, fervent jubilation. $^{92}$

In the early years of the PRC, the enclosed square and the ancient gates leading to it had been a major problem for parade planners. Archival sources indicate that, as early as 1950, congestion during the May Day and May Fourth parades caused grave concern among senior officials. Nie Rongzhen (聂荣臻,

87 Beijing jianshe shishu bianji weiyuanhui (ed.), Jianguo yilai de Beijing chengshi jianshe (The Urban Construction of Beijing since the Founding of the Nation) (Beijing: n. p., 1986), pp. 23-61.

88 Mao Zedong, "The May Fourth Movement," in Mao Tse-tung, Selected Works of Mao Tse-tung, 5 vols. (Peking: Foreign Languages Press, 1967-77), Vol. 2, pp. 237-39.

89 Renmin ribao, 27 September 1959.

90 A number of Soviet urban planners and architects such as A. S. Mukhin and D. D. Baragin arrived in Beijing in the early 1950s to help redesign Tiananmen Square. See Chang-tai Hung, "Kongjian yu zhengzhi: kuojian Tiananmen guangchang" ("Space and politics: expanding Tiananmen Square"), paper presented at the symposium on "Cross-Strait Political and Economic Developments during the Cold War," the Institute of Modern History, Academia Sinica, 4-5 November 2004.

91 Greg Castillo, "Gorki Street and the design of the Stalin revolution," in Zeynep Çelik, Diane Favro and Richard Ingersoll (eds.), Streets: Critical Perspective on Public Space (Berkeley: University of California Press, 1994), pp. 57-70.

92 Richard Stites, Revolutionary Dreams: Utopian Vision and Experimental Life in the Russian Revolution (New York: Oxford University Press, 1989), p. 243. 
1899-1992), then mayor of Beijing, reported that "the narrowness of [East and West] Sanzuomen could only allow 23 people to pass through side by side ... With a total number of 200,000 marchers, it would take four-and-a-half hours to conclude the entire procession. The traffic was jammed and the participants exhausted."93 Thus a suggestion was made in 1955 to build avenues that could accommodate "a million marchers during the grand parades.",94

The expansion of Tiananmen Square went through several phases. In August 1949, two months before the founding of the PRC, the municipal Party decided to expand the square so that "it could accommodate 160,000 people.",95 Mao was said to have issued an order to enlarge the square so that it could accommodate "a million people." 96 The square was further expanded in the late 1950s to commemorate the tenth anniversary of the founding of the PRC, and by 1959 it reached the mammoth size of 44 hectares. ${ }^{97}$ Under the reconstruction plan, the Chang'an Gates on the east and west side of Chang'an Avenue, as well as the old walls surrounding the square, were removed. The marchers who formed the next circle could now move westward from Dongdan directly into Tiananmen Square. Then came the pre-selected participants in the square, who advanced to Gold Water Bridge to cheer for the Party leaders, thus completing the next ring in the spatial hierarchy. Atop Tiananmen, senior Party leaders such as Zhu De and Zhou Enlai formed the innermost circle, with Chairman Mao at the heart of the entire ceremony.

In his study of the symbolics of power, Clifford Geertz contends that centrality and sacredness are closely linked. Political centres therefore often form the most sacred, charged space. ${ }^{98}$ The pre-eminence of Mao's status in the holiday celebrations was unambiguous, as were his supreme authority and sacred stance in the Party and the nation. It was the chairman who officially announced the founding of a new nation on 1 October 1949; his giant portrait graced the front of Tiananmen; he was the only leader to receive bouquets from the two representatives of the Young Pioneers during the National Day parades; ${ }^{99}$ his portrait was always carried first among all Chinese leaders; and the newly invented tradition of the crowd "advancing to Gold Water Bridge" centred on him as China's supreme leader. At the core of that symbolic world, Mao stood supreme.

93 For Nie Rongzhen's report, see Beijing Urban Construction Archives, C2-46-2.

94 "Tiananmen guangchang dongxi liangduan daolu xitong sheji shuomingshu" ("An illustration of the design of Tiananmen Square's road system to the east and west"), Beijing Urban Construction Archives, C2-46-2.

95 "Tiananmen qian jiang pi guangchang" ("A square will be created in front of Tiananmen"), Renmin ribao, 31 August 1949.

96 Shu Jun, The Historical Documents of Tiananmen Square, p. 25.

97 "Tiananmen guangchang gongcheng de jiben qingkuang" ("The basic conditions of the Tiananmen Square project"), BMA, 47-1-92.

98 Geertz, "Centers, kings, and charisma," pp. 121-46.

99 Solemn Festivities, p. 321. This practice, however, was ended in 1954. 


\section{Chinese Compared to Soviet Spectacles}

Were the Chinese spectacles influenced by the Soviet Union? Although information on this issue is sketchy, evidence indicates that Soviet patterns were admired, studied and to some extent followed. Early CCP leaders clearly were awed by the Soviet parades. During his stay in Moscow in the early 1920s, Qu Qiubai (翟秋白, 1899-1935) watched with great admiration the workers and peasants dancing in Red Square during the May Day parade. "This is a joyous festival [jiajie 佳节]," praised Qu. ${ }^{100}$ In the early years of the PRC, Chinese organizers sought advice from Soviet military advisers regarding military parades, and also consulted senior Chinese Party leaders, including General Liu Bocheng (刘伯承, 1892-1986), who had been trained at the military institute in Moscow and were familiar with the Soviet parades. ${ }^{101}$ In 1954, a Beijing municipal officer, Zeng Ping (曾平), was sent to the Soviet capital to study the processions. He reported that Soviet parades, as in China, saw workers and students as the key representative groups, although the Russians made less of a distinction in their group formations and their processions were marked by a freer spirit. ${ }^{102}$

Surely there are many parallels between the two countries in their respective state festivals. Like the Soviets, who regarded May Day and the anniversary of the October revolution as their most important holidays, the Chinese considered the May Day and National Day parades as their foremost public celebrations. As in the early history of the Soviet Union, a high degree of revolutionary enthusiasm prevailed in the early Chinese parades. However, clear differences also existed between the two. The early Bolshevik festivals, as pointed out by James von Geldern, were influenced by a pre-1917 avant-garde spirit, and festivities were spontaneous and creative, with talented artists and playwrights drawing freely from artistic traditions. ${ }^{103}$ Many voluntary participants took part in the early Russian state events, as in the May Day celebration in Leningrad in 1925 when 200,000 people, 21 per cent of the city's population, were involved, and grassroots activities were common. ${ }^{104}$ Nevertheless, the increasing dominance of Stalinism and the expansion of political control in the 1930s resulted in fewer popular initiatives and a stale uniformity in the mass public holidays in later years.

In contrast, the CCP exercised a firm grip on every element of the events from the very beginning. Marchers were carefully selected and audiences along procession routes vigilantly monitored, especially those on the main thoroughfares such as East and West Chang'an Avenues. Those who were summoned to

100 Qu Qiubai, "Chidu xinshi" ("Impressions of the red capital seen through the mind"), in Qu Qiubai wenji (Collected Writings of Qu Qiubai), Vol. 1 (Beijing: Renmin wenxue chubanshe, 1985), p. 145.

101 Solemn Festivities, p. 5.

102 "Yijiuwusi nian ba yue si ri guoqingjie choubeihui" ("The preparatory committee meeting on 4 August 1954 concerning the National Day festival"), BMA, 99-1-33.

103 James von Geldern, Bolshevik Festivals, 1917-1920 (Berkeley: University of California Press, 1993), pp. $40-71$.

104 Lane, The Rites of Rulers, pp. 169-72. 
stay in the square as part of the overall ceremony, numbering from 50,000 to 100,000 on different occasions, were even more painstakingly screened. ${ }^{105}$ These mammoth events were state-managed down to the most minute details.

Early Soviet parades also witnessed a carnivalesque spirit that often enlivened popular revelries. This was particularly evident in the attack against enemies through ridicules in the parades, as in the burning of effigies of the kulak on Red Square and the presentation of enemies as zoo animals in the procession. ${ }^{106}$ The Chinese Communists, however, prohibited negative symbols of enemies. ${ }^{107}$ When a county in Hebei province portrayed Harry Truman and Douglas MacArthur in the National Day celebrations in 1951, an article in Renmin ribao condemned the act as outlandish: "When do we ever see reactionaries such as Harry Truman, Chiang Kai-shek, Syngman Rhee, and Yoshida [Shigeru] dancing happily together with the working people?"108

\section{Problems with the Processions}

The CCP clearly attached great significance to the two major political spectacles. And, indeed, the sheer volume of the parades, the colourful floats, the marchers' elegant precision and the festive spirit made the events truly impressive, winning accolades from foreign observers. "In the future, China would become the strongest nation in the world," reportedly praised one foreign guest after viewing the 1955 National Day celebrations. Another commented, "Chiang Kai-shek would cry if he had seen such a parade."109

But despite meticulous planning and tight control, the spectacles never went as smoothly as the officials would like the public to believe. Not surprisingly, the major headache came from the effort to co-ordinate hundreds of thousands of marchers before, during and after the processions. Complaints were often heard that participants were not marching in unison and were sometimes running to make up for missing steps. The ritual "advancing to Gold Water Bridge," with countless people pushing towards Tiananmen, often resulted in accidents, sometimes serious ones. In the 1955 May Day celebrations, for example, many people were injured. "It could leave a bad impression on foreign guests," one reporter warned. ${ }^{110}$

105 "Zuzhi qunzhong zai Xi Chang'anjie canguan yuebin, youxing de gongzuo jihua" ("The work plan for organizing people to view the military parade and the procession along West Chang'an Avenue"), BMA, 99-1-75. In this document Mao was reported to have said, "The people have now been highly organized."

106 Victoria Bonnell, The Iconography of Power: Soviet Political Posters under Lenin and Stalin (Berkeley: University of California Press, 1997), p. 193; Lane, The Rites of Rulers, p. 168.

107 Of course negative symbols such as the paper tiger were used during the anti-imperialist demonstrations, as in the "Resist America and aid Korea" campaign in the early 1950s. See Renmin ribao, 18 December 1950.

108 Renmin ribao, 18 February 1951.

109 "Waibin dui youxing duiwu de fanying" ("Foreign guests' reactions to the parades"), BMA, 99-1-48.

110 "Zhongzhi ge jiguan tongzhi dui Wuyi youxing de yijian" ("Opinions of the comrades of the central bureaus concerning May Day parades"), BMA, 99-1-48. 
The night-time firework display was another concern. In April 1955, in a preparatory meeting for the May Day parade, some recalled that wooden buildings in the old imperial palace were burned down a number of times in the Ming and Qing dynasties. As a precautionary measure, Peng Zhen ordered the palace to shut for three days prior to 1 May. ${ }^{111}$

Ironically, festivities notwithstanding, the two major celebrations were operated under extremely tight security. The military and subversive threat from Kuomintang forces both inside and outside mainland China was always in the organizers' minds. The air attacks against Shanghai's power plant in February 1950, mentioned earlier, was fresh in everyone's memory. Air drills were mounted and air defence systems activated in each parade. ${ }^{112}$ Every year, as revealed in a 1956 archival document, "[anti-government] reactionary slogans are discovered," although the source gives no specific details. ${ }^{113}$ What if enemy planes did attack during the procession? Marchers were instructed by the organizers to obey commands issued by the parade command centres. In the words of Peng Zhen, "whether it is air raids, the dropping of atomic bombs, hydrogen bombs, rain or hailstones, we must carry on as planned. People must remain in place!" 114 Hyperbolic tone notwithstanding, Peng's instruction reflected his concern about the deadly consequences that could have ensued had chaotic conditions erupted. During the 1954 National Day procession, rain caused confusion and resulted in several people being trampled and killed in a stampede at the exit. ${ }^{115}$

\section{Conclusion}

In a preparatory session, Peng Zhen delineated what he regarded as the main goals of the state spectacles: "Parades are a grand demonstration against imperialism. They display our strength and can have an influence on capitalist countries." $" 116$ To achieve this, he instructed, the processions must be staged in "the most overwhelming way." ${ }^{117}$ But Peng's terse comment touched only on the most general aspects of the parades. In reality, as I argue in this article, parades were a complicated political text that functioned as a means of glorification, legitimation, hero worship and nationalism. The two annual state spectacles could be read, on the surface, as a self-congratulatory party thrown by the CCP.

111 "Beijing qingzhu yijiuwuwu nian 'Wuyi' laodongjie choubei huiyi” ("Preparatory meeting for the celebration of the 1955 May Day festival in Beijing"), BMA, 99-1-60. But the document does not indicate what safety measures were taken.

112 Ibid.

113 Ibid.

114 "Peng Zhen tongzhi zhaoji de guoqingjie youxing ji baowei gongzuo huiyi" ("The meeting called by Comrade Peng Zhen concerning the National Day parades and their security matters"), BMA, 99-178.

115 Solemn Festivities, p. 187.

116 "The third meeting of the command centre."

117 "The meeting called by Comrade Peng Zhen concerning the National Day parades and their security matters." 
But essentially they were a calculated measure by the CCP to remake its own image every year, as well as to relive the revolution. Parades in Tiananmen Square, with their highly flamboyant pageantry, were meant to be seen in their grandest manner. They were intended to propagate the Party's political agenda by imposing a uniform socialist vision upon a young nation, to draw popular support for the regime's legitimacy, to underscore the centrality of Mao and to imbue national pride. The military parade and the civilian processions were designed to demonstrate the harmony between the people and a beloved Party, and to awe opponents into submission. True, Chinese spectacles were influenced by their Soviet counterparts, but the foreign model was adapted to meet China's needs and never followed blindly. Clearly the victory of the CCP in 1949 was propelled largely by its nationalistic appeal to establish China as an independent nation. A parade based entirely on a foreign model, even the Soviet one, without distinct indigenous characteristics, could undermine the government's popular support and ultimately its legitimacy.

The issue of control was one of the most salient aspects of these parades. Indeed, the two public celebrations enabled the Party to mount a grand ritual through its multilayered state machinery. The uncertainties of the time (the Korean War) and the real and imagined threats from internal enemies (capitalists and spies) and external ones (the Kuomintang and American imperialists) no doubt required the government to be extremely vigilant. But, more importantly, the very nature of the CCP called for firm control of the populace and demanded political and artistic conformity. Unlike the pluralistic character of early Soviet parades, the CCP's tight control of the mass holidays occurred from the early days of the People's Republic. Initial popular elation about the new regime notwithstanding, little audience participation was allowed in the parades. The subsequent standardization of the planning also resulted in increased conformity of all aspects of the mass holidays. True, standardization is an essential feature of all rituals, for it provides a sense of permanence. ${ }^{118}$ But it also can easily degenerate into ossification, and that was precisely the case in China. Before long the Chinese state spectacles became uniform, repetitive, predictable and devoid of creativity.

In his study of the Red Square celebrations, Vladimir Paperny raised a question: "Who were the spectators of the pompous parades and demonstrations of the 1930s?" His answer was that "the leaders were not the audience, they were the actors, while the demonstrators acted as [the] audience," for "the 'nonparticipating, but applauding' audience was 'hauled' in front of the stage [Lenin Mausoleum] to give everybody a chance to see the 'king and his staff'."119 This observation can be equally applied to the Chinese case. The Chinese marchers and the prescreened attendants in Tiananmen Square were carefully chosen to take part in the state spectacles. In the processions, marchers were not

118 David I. Kertzer, Ritual, Politics and Power (New Haven: Yale University Press, 1988), p. 42.

119 Vladimir Paperny, "Moscow in the 1930s and the emergence of a new city," in Hans Günther (ed.), The Culture of the Stalin Period (New York: St Martin's Press, 1990), p. 232. 
simply actors but also members of the audience, wanting both to see and to be seen. "Advancing to Gold Water Bridge" was a ritualistic finale during which marchers as actors turned quickly into an audience, eager to see the real actors, that is, Mao and his senior leaders, on the sacred stage of Tiananmen. In my recent interviews with a number of those who marched in the processions in the early days of the PRC, many still spoke with great excitement of rushing to Gold Water Bridge to see their admired leaders, especially Chairman Mao. "Immediately after the procession," one parader reminisced, "we advanced to Gold Water Bridge, standing beneath Tiananmen. Chairman Mao walked towards us on top of the gate, holding his hat, saying, in a Hunanese accent, 'Long live the Chinese People!"' 120 It was a magical moment when the chairman and the masses united, affirming the Party's right to represent and speak for the people. In the end, Mao and other senior Party members were not only the actors, but, more significantly, they were the directors commanding every move of the marchers - the audience - in the ceremonies. The Party was always at the helm, directing the preselected audience, carefully choreographing and herding them into the vast square, the ritual stage, to heap praise on the Party and its god-like chairman. 